\title{
Effect of breed type and ionophore supplementation on growth and carcass characteristic in feedlot hair lambs
}

\author{
Jaime Salinas-Chavira ${ }^{1}$, Alfredo Lara-Juarez ${ }^{1}$, Abraham Gil-González ${ }^{1}$, Jorge Jimenez- \\ Castro $^{2}$, Ramón Garcia-Castillo ${ }^{3}$, Efrén Ramírez-Bribiesca ${ }^{4}$
}

${ }^{1}$ Facultad de Medicina Veterinaria y Zootecnia, Universidad Autónoma de Tamaulipas.

2 Facultad de Zootecnia, Universidad Autónoma de Chihuahua.

${ }^{3}$ Universidad Autónoma Agraria Antonio Narro.

${ }^{4}$ Colegio de Postgraduados, enlace Ganadería, Montecillo, Texcoco, Edo. de México.

ABSTRACT - The effects of supplementing feedlot diets with ionophores and breed type were assessed on growth rate and carcass characteristics in hair lambs. Twenty four intact males, 12 Pelibuey $\times$ Dorper (PDo) and 12 Pelibuey $\times$ Damara (PDa) lambs, $17.9 \pm 3.7 \mathrm{~kg}$ initial weight, were housed in individual pens for a 60 -d feeding trial. The lambs were assigned randomly into four diets: control without additives (C); $25 \mu \mathrm{g} / \mathrm{g}$ monensin (M); $28 \mu \mathrm{g} / \mathrm{g}$ salinomycin (S); $28 \mu \mathrm{g} / \mathrm{g} \mathrm{S}$ for $20 \mathrm{~d}$, and $25 \mu \mathrm{g} / \mathrm{g}$ M for the next $40 \mathrm{~d}$ (SM). Each diet was supplied to six lambs. Data were analyzed as a randomized complete block design in a $4 \times 2$ factorial arrangement, with four diets and two breed types of hair lambs (PDo and PDa). All diets were formulated to contain $14 \% \mathrm{CP}$ and $2.6 \mathrm{Mcal} \mathrm{ME} / \mathrm{kg}$ dry matter. At the end of the feeding trial carcass images were recorded in the last intercostal space $\left(12^{\text {th }}\right.$ and $13^{\text {th }}$ ribs) using ultrasound equipment to measure the Longissimus dorsi muscle area and subcutaneous fat $(\mathrm{SF})$. The average daily gain (ADG), daily dry matter intake, feed:gain ratio, subcutaneous fat and Longissimus dorsi area were not affected by ionophore supplementation.. The Pelibuey $\times$ Dorper group tended to show better average daily gain than Pelibuey $\times$ Damara $(262 \mathrm{~g} / \mathrm{d}$ and $235 \mathrm{~g} / \mathrm{d}$, respectively). Daily dry matter intake, feed:gain ratio and subcutaneous fat were not affected by breed type. The Pelibuey $\times$ Dorper lambs had greater Longissimus dorsi area $\left(16.74 \mathrm{~cm}^{2}\right)$ than the Pelibuey $\times$ Damara $\left(14.29 \mathrm{~cm}^{2}\right)$ lambs. The growth rate was not influenced by the inclusion of ionophores. Pelibuey $\times$ Dorper lambs showed better average daily gain and carcass characteristics than Pelibuey $\times$ Damara lambs.

Key Words: feed additives, hair lambs, fattening, Longissimus dorsi, subcutaneous fat

\section{Efeito do grupo genético e da suplementação com ionóforos sobre o crescimento e as características de carcaça de cordeiros deslanados confinados}

RESUMO - Avaliaram-se os efeitos da suplementação de dietas de confinamento com ionóforos e da raça do animal na taxa de crescimento e nas características de carcaça de cordeiros deslanados. Vinte e quatro machos não-castrados - 12 cordeiros Pelibuey $\times$ Dorper $($ PDo) e 12 cordeiros Pelibuey $\times$ Damara $(P D a)$, com $17.9 \pm 3.7 \mathrm{~kg}$ de peso inicial - foram confinados em baias individuais, em um experimento de 60 dias. Os cordeiros foram distribuídos aleatoriamente em quatro dietas (D): controle sem aditivos; $25 \mu \mathrm{g} / \mathrm{g}$ de monensina; $28 \mu \mathrm{g} / \mathrm{g}$ de salinomicina; $28 \mu \mathrm{g} / \mathrm{g}$ de salinomicina durante 20 dias, e $25 \mu \mathrm{g} / \mathrm{g}$ de monensina pelos próximos 40 dias. Cada dieta foi fornecida a seis cordeiros. Os dados foram analisados em delineamento inteiramente casualizado em esquema fatorial $4 \times 2$; com 4 dietas e 2 raças deslanadas (PDo and PDa). Todas as dietas foram formuladas para conter $14 \%$ de proteína crua (PC) e 2.6 Mcal de energia metabolizável (EM) $/ \mathrm{kg}$ de matéria seca (MS). Ao final do experimento, imagens da carcaça eram gravadas no último espaço intercostal (12 ${ }^{\mathrm{a}}$ e $13^{\mathrm{a}}$ costelas), usando-se um equipamento de ultrassom para medir a área de olho-de-lombo e a gordura de cobertura (GC). O ganho de peso diário (GPD), o consumo diário de matéria seca, a conversão alimentar, a gordura de cobertura e a área de olho-de-lombo não foram afetados pela suplementação com ionóforos. O grupo Pelibuey $\times$ Dorper tendeu a maior ganho de peso diário em comparação ao Pelibuey $\times$ Damara $(262 \mathrm{~g} /$ dia e $235 \mathrm{~g}$ /dia, respectivamente). O consumo diário de matéria seca, a conversão alimentar e a gordura de cobertura não foram afetados pelo grupo genético dos animais. Os animais Pelibuey $\times$ Dorper $\left(16.74 \mathrm{~cm}^{2}\right)$ apresentaram maior $(\mathrm{P}<0.05)$ área de olho-de-lombo em relação aos Pelibuey $\times$ Damara $\left(14.29 \mathrm{~cm}^{2}\right)$. A taxa de crescimento não foi influenciada pela inclusão de ionóforos na dieta. Cordeiros Pelibuey $\times$ Dorper podem ter maior ganho de peso diário e melhores características de carcaça que cordeiros Pelibuey $\times$ Damara.

Palavras-chave: aditivos para alimentos, cordeiros, engorda, gordura subcutânea, Longissimus dorsi, pelos 


\section{Introduction}

Sheep production in the Mexican (dry and humid) tropics is mainly based on hair breeds such as the Pelibuey, and recently Kathadin, Dorper, Damara, and others. Alvarez et al. (2004) reported higher weight gain for Dorper x Pelibuey and Katahdin x Pelibuey than Pelibuey. But now the Dorper breed is preferred among producers and their population is increasing. Further research is required on this breed to evaluate the productive parameters in feedlot programs.

The positive effects of Dorper on growth performance and carcass characteristics have been reported by Burke et al. (2003). Damara has also shown positive characteristics; Fleet et al. (2002) compared Merino ewes mated with Merino rams and Damara fat tail rams. There was advantage in the mating with the Damara rams which produced multiple litters, high 5-month live weights and high dressing percentage at slaughter but the crossbred groups had more external carcass fat and fat tail weights than the Merino groups.

Feed additives such as the ionophores monensin and salinomycin are used for feedlot lambs. Salinas-Chavira et al. (2005b) observed that lambs on salinomycin had higher weight gain, feed intake and Longissimus dorsi area than those on monensin; both groups of lambs showed similar subcutaneous fat contents. The addition of inophores to diets has been extensively studied, which have a limited response to feed conversion and weight gain. Exchanging ionophore during feeding may improve this limited response and improve productive parameters. A previous study showed that salinomycin and consecutive monensin supply to lambs in feedlot may have a positive effect on growth performance or feed:gain ratio, because salinomycin allows higher feed intake than monensin in feedlot lambs (Salinas-Chavira et al., 2005b). Similarly there is little information on the use of these ionophores use in feedlot lambs considering the Dorper and Damara breeds crossbred with Pelibuey. The objetives of the present research were to evaluate the effects of ionophore supplementation on the growth rate and carcass characteristics of feedlot lambs of different breeds.

\section{Material and Methods}

The research was conducted at the University of Tamaulipas in Ciudad Victoria, Mexico. This city is located at $23^{\circ} 44^{\prime} 06^{\prime \prime} \mathrm{N}$ and $97^{\circ} 09^{\prime} 50^{\prime \prime} \mathrm{W}$, at an altitude of $340 \mathrm{~m}$. The annual mean temperature of the region is $25^{\circ} \mathrm{C}$, with $900 \mathrm{~mm}$ annual precipitation (INEGI, 1995).
Twelve Pelibuey $\times$ Dorper and twelve Pelibuey $\times$ Damara intact male lambs of $17.9 \pm 3.7 \mathrm{~kg}$ were randomly distributed in a factorial arrangement to four diet groups: control, no additive; monensin $(25 \mu \mathrm{g} / \mathrm{g}$ feed $)$ throughout the trial; salinomycin (28 $\mu \mathrm{g} / \mathrm{g}$ g feed) throughout the trial; and salinomycin the first 20 days and monensin for the last 40 days of the trial. Each diet was supplied to six lambs (3 Pelibuey $\times$ Dorper plus 3 Pelibuey $\times$ Damara lambs). Lambs were three months old.

All lambs received a diet of $58.5 \%$ ground sorghum grain, $16.9 \%$ soybean meal, $10 \%$ sorghum hay, $6.8 \%$ wheat bran, $4 \%$ sugar cane molasses, $2 \%$ mineral premix (containing: Ca 100 g, P 80 g, Mg 30 g, Zn 4 g, Mn 3 ppm, $\mathrm{Fe} 3 \mathrm{ppm}, \mathrm{Cu} 0.0025 \mathrm{~g}$, I 0.04 g, Se 0.04 g, Co $0.02 \mathrm{~g}$; qs. $1 \mathrm{~kg}), 1.5 \%$ low ruminally bioutilizable fat and $0.3 \%$ urea (14\% crude protein and $2.6 \mathrm{Mcal} / \mathrm{kg}$ metabolizable energy) to meet the requirements of growing lambs (NRC, 2007). Monensin was included in the diet at $25 \mu \mathrm{g} / \mathrm{g}$ monensin - the level commonly used for feedlot cattle, and used by Salinas-Chavira et al. (2005b) - and salinomycin at $28 \mu \mathrm{g} / \mathrm{g}$ (based on the study by Medeiros et al., 1999; Salinas-Chavira et al. 2005b). All the lambs were housed in individual pens $\left(2 \mathrm{~m}^{2}\right)$. Before the experimental feeding period that lasted 60 days, the lambs were adapted to the diet for 15 days; during that time, they were treated conventionally for fattening lambs. Lambs received the diet twice daily ( 9 a.m. and 4 p.m.), and had free access to water.

During the experimental period, diets were offered twice daily (9 a.m. and 4 p.m.). Daily feed intake was adjusted on an offered-less-refused and was controlled. The lambs were weighed four times: at the beginning of the feeding period, and every 20 days.

At the end of the feeding trial, the carcass characteristics were measured with ultrasound (Aloka, model SSD-500) using a 7.5 MHz linear transducer. Images were taken on the last intercostal space (between the $12^{\text {th }}$ and $13^{\text {th }}$ ribs) on both sides, after shaving approximately $25 \mathrm{~cm}^{2}$ to provide proper contact. The longissimus dorsi muscle area (sum of both sides, $\mathrm{cm}^{2}$ ) and subcutaneous fat depth (average of both sides, $\mathrm{cm}$ ) were measured using the measuring accessories in the equipment.

The data were subjected to analysis of variance in a completely randomized design using a $4 \times 2$ factorial arrangement: factor $\mathrm{A}$, with four ionophore groups (control, monensin, salinomycin, and salinomycin $\times$ monensin), and factor B with two breed types (Pelibuey $\times$ Dorper and Pelibuey $x$ Damara). Means were compared $(\mathrm{P}<0.05)$ by Tukey test (Steel \& Torrie, 1980). 


\section{Results and Discussion}

There were no interactions $(\mathrm{P}>0.05)$ between dietary ionophores and breed type on the growth rate and carcass characteristics of the lambs (Table 1). Ionophore did not affect $(\mathrm{P}>0.05)$ the weight gain of lambs. In agreement with Salinas-Chavira et al. (2005a) in feedlot lambs there was no effect of $25 \mu \mathrm{g} / \mathrm{g}$ sodium monensin in the diet on weight gain. Consistent with these results, Santos (2005) in lambs obtained $275,291,301$ and $285(\mathrm{~g} / \mathrm{d})$ with $0,21.35,43.25$ and 65.62 monensin $(\mu \mathrm{g} / \mathrm{g}$ feed); there was no effect of monensin on weight gain. This sense, Tedeschi et al. (2003) pointed out that ionophore effects on animal performance may vary depending on dosage, animal, and diet.

Published data state that monensin and salinomycin improve cellulose digestion of diets high in readily available carbohydrate by inhibiting the growth of lactate-producing bacteria, thereby decreasing lactate concentrations and increasing ruminal $\mathrm{pH}$, passage rate, feed efficiency and daily weight gains (Russell \& Strobel 1989; Wallace, 1994). Some researchers have demonstrated that during long-term supplementation the beneficial effects of monensin on the ruminal fermentation have decreased (Lana et al., 1997). Interestingly, a ionophore rotation scheme has been shown to improve feed efficiency more than feeding a single ionophore (Galyean \& Hubbert, 1989). But this effect was not observed in the present study, there was no effect $(\mathrm{P}>0.05)$ of ionophore supplementation on feed intake. These results are in agreement with Rangel \& Nuñez (1992) and Salinas-Chavira et al. (2005a) who did not find effect on feed intake of lambs fed monensin with the concentrate. Santos (2005) also reported no consequence of monensin on dry matter intake. In contrast, Salinas-Chavira et al. (2005b) reported higher feed intake for lambs on salinomycin than monensin. Some factors may have contributed to this situation. In grain-based feedlot diets, feed efficiency has been improved by reducing dry matter intake with little or no effect on average daily gain (Tedeschi et al., 2003). Diet composition influences the growth responses to monensin addition in diets. Clary et al., (1993) observed no effect of monensin on net energy for maintenance $\left(\mathrm{NE}_{\mathrm{m}}\right)$ when $4 \%$ tallow was added to the diet; however, in the control ( $0 \%$ tallow), monensin increased $\mathrm{NE}_{\mathrm{m}}$ of the diet by $5.1 \%$ and net energy for gain $\left(\mathrm{NE}_{\mathrm{g}}\right)$ by $7 \%$ in feedlot cattle fed high-grain diets. Growth response to monensin is also related to the forage level in the diet. According to Tedeschi et al. (2003) there is a reduction in monensin response with increasing levels of Me in the feed; this partially explains the higher response to monensin in pasture-based diets. There was no effect $(\mathrm{P}>0.05)$ of ionophore on the feed:gain ratio. Salinas-Chavira et al. $(2005 \mathrm{a}, \mathrm{b})$ did not find ionophore effect on feed:gain ratio in feedlot lambs. In contrast, Santos (2005) reported that lambs fed $43.25 \mu \mathrm{g} / \mathrm{g}$ monensin in the diet presented the best feed:gain ratio. The different responses may be attributable to the monensin dose; $25 \mathrm{mg} / \mathrm{g}$ monensin was used in the present study. Similarly, Medeiros et al. (1999) reported better feed:gain ratio in lambs fed $28 \mu \mathrm{g} / \mathrm{g}$ salinomycin.

Ionophores have been proven to alter fatty acid concentrations in the rumen. They have a basic mode of action, modifying the movement of ions across biological membranes, increasing propionate production in the rumen while decreasing acetate and butyrate percentages (Wallace, 1994). In this case, Smith \& Crouse (1984) suggested that different regulatory processes are controlled de novo by fatty acid synthesis in intramuscular and subcutaneous adipose tissue. They showed that acetate provides 70 to $80 \%$ of the acetyl units to lipogenesis in subcutaneous fat, and conversely glucose, whose precursor is propionate, was shown to provide 50 to $75 \%$ of the acetyl units in the intramuscular depot. Thus, manipulating the acetate and propionate concentration has

Table 1 - Lamb growth rate and carcass characteristics

\begin{tabular}{|c|c|c|c|c|c|c|c|c|}
\hline \multirow[t]{2}{*}{ Item } & \multicolumn{4}{|c|}{ Diets } & \multirow[t]{2}{*}{ SEM } & \multicolumn{2}{|c|}{ Breed Type } & \multirow[t]{2}{*}{ SEM } \\
\hline & Control & Mon & Sal & Sal-Mon & & $\mathrm{P} \times \mathrm{Da}$ & $\mathrm{P} \times \mathrm{Do}$ & \\
\hline \multicolumn{9}{|l|}{ Growth performance } \\
\hline Weight gain, g/d & 241.5 & 244.2 & 250.0 & 258.5 & 15.2 & 235.2 & 261.9 & 10.7 \\
\hline Feed intake, g/d & 1079.6 & 1120.3 & 1088.0 & 1154.3 & 62.9 & 1074.7 & 1146.5 & 44.5 \\
\hline Feed efficiency & 4.5 & 4.7 & 4.5 & 4.5 & 0.3 & 4.6 & 4.5 & 0.2 \\
\hline \multicolumn{9}{|l|}{ Carcass characteristics } \\
\hline Subcutaneous fat, $\mathrm{cm}$ & 0.220 & 0.220 & 0.230 & 0.230 & 0.008 & 0.225 & 0.235 & 0.053 \\
\hline Longissimus dorsi, $\mathrm{cm}^{2, b}$ & 14.77 & 15.15 & 15.59 & 16.64 & 1.09 & 14.29 & 16.74 & 0.77 \\
\hline
\end{tabular}

Mon $=$ monensin, Sal $=$ Salinomycin

$\mathrm{P} \times \mathrm{Da}=$ Pelibuey $\times$ Damara; $\mathrm{P} \times \mathrm{Do}=$ Pelibuey $\times$ Dorper .

$\mathrm{SEM}=$ Standard error mean.

a Breed effect $(\mathrm{P}<0.10)$.

${ }^{\mathrm{b}}$ Breed effect $(\mathrm{P}<0.05)$ 
potential to alter fat deposition in lambs. However, in the present study the subcutaneous fat and Longissimus dorsi area were not affected $(\mathrm{P}>0.05)$ by ionophores. In agreement with the present experiment, the lack in response to ionophore supplementation on subcutaneous fat in feedlot lambs was also reported by Salinas-Chavira et al. (2005a,b). On the other hand, greater Longissimus dorsi area was observed in lambs receiving monensin than in the control group (Salinas-Chavira et al., 2005a); and greater Longissimus dorsi area was observed in lambs supplemented with salinomycyn than those receiving monensin (Salinas-Chavira et al., 2005b). Ionophores in the diet improve efficiency of energy use (feed to gain ratio) because of more efficient ruminal fermentation, increasing propionate and reducing acetate, with fall in methane production and degradation of dietary protein in the rumen (Tedeschi et al., 2003). However these changes were not reflected in the back fat deposition or muscle accretion for lambs in the present study, since fat accumulation on body deposits are influenced by diet composition and lamb age (Leon et al., 1999).

Pelibuey $\times$ Dorper gained $11.4 \%$ more than Pelibuey $\times$ Damara lambs $(\mathrm{P}<0.10)$. Other studies on feedlot lambs (Alvarez et al., 2004; Alvarez et al., 2005) reported higher weight gains for Dorper than Pelibuey lambs. Similarly, Burke \& Apple (2007) found that Dorper and Suffolk whether lambs had greater average daily gain from weaning to slaughter than SC or KA whether lambs and Burke et al. (2003) concluded that improvements in live animal performance can be achieved by using Dorper sires on purebred and crossbred St. Croix dams. There was no effect $(\mathrm{P}>0.05)$ of breed on feed intake. Pelibuey $\times$ Dorper and Pelibuey $\times$ Damara lambs had daily feed intake of 1147 and $1075 \mathrm{~g} / \mathrm{d}$, respectively. There was no effect $(\mathrm{P}>0.05)$ of breed on feed efficiency. Pelibuey $\times$ Dorper and Pelibuey $\times$ Damara lambs had feed conversion of 4.47 and of 4.6 , respectively.

Subcutaneous fat was not affected $(\mathrm{P}<0.05)$ by breed. The Pelibuey $\times$ Dorper and Pelibuey $\times$ Damara groups had subcutaneous fat of 0.24 and $0.23 \mathrm{~cm}$, respectively. Breed effects on subcutaneous fat could be expected in the present experiment. Consistently, Burk \& Apple (2007) used 3/4 or 7/8 Dorper, purebred Katahdin, purebred St. Croix and purebred Suffolk lambs. After weaning, the lambs were supplemented with up to $680 \mathrm{~g}$ of a cornsoybean meal supplement while grazing bermudagrass pastures overseeded with ryegrass. The lambs were slaughtered at approximately $210 \mathrm{~d}$ of age. On pure breed whether lambs, carcasses of Katadin lambs had more fat thickness than carcasses of Dorper x St. Croix, or Suffolk lambs. Carcasses of Katadin lambs were fatter (actual fat thickness; $\mathrm{P}<0.02$ ) resulting in higher yield grades $(\mathrm{P}<0.03)$ than carcasses of Dorper lambs. However, the crossbreds of Dorper $\times$ St. Croix, Dorper $\times$ Romanov $\times$ St. Croix, Katahdin, and 3/4 St. Croix-1/4 Romanov carcasses had greater fat thickness than St. Croix carcasses.

Pelibuey $\times$ Dorper lambs had greater $(\mathrm{P}<0.05)$ Longissimus dorsi area than Pelibuey $\times$ Damara lambs (Table 1). In agreement with this result, the Dorper lambs are recognized for their ability to produce leaner carcass and more muscularity (Burke et al., 2003); in Damara lambs, Fleet et al. (2002) reported that dressing percentage at slaughter of the crossbred lambs (Damara $\times$ Merino) was $3-4 \%$ higher, reflecting lower wool production, than the Merino lambs. Also crossbred groups had more external carcass fat (2.59 and $2.64 \mathrm{~kg})$ than the Merino groups (2.14 and $2.15 \mathrm{~kg}$ ) and, in addition, crossbreds had fat tail weights of 0.52 and $0.36 \mathrm{~kg}$. Because of the limited information on the Damara breed, it is difficult to compare them with Dorper animals when they are crossbred with Pelibuey. In the present study, the Pelibuey $\times$ Dorper lambs had greater Longissimus dorsi area than Pelibuey $\times$ Damara lambs.

\section{Conclusions}

The growth rate of lambs was not influenced by the inclusion of ionophores. The Pelibuey $\times$ Dorper lambs showed higher live weight gain and carcass characteristics than the Pelibuey $\times$ Damara lambs.

\section{References}

ALVAREZ, V.F.D.; AVENDAÑO, R.L.; MOLINA, R.L. et al. Comportamiento en corral de cruzas de borrego Pelibuey y en la época de verano-otoño. In: REUNIÓN INTERNACIONAL SOBRE PRODUCCIÓN DE CARNE Y LECHE EN CLIMAS CÁLIDOS, 14., 2004, Mexicalí. Proceedings... Mexicalí: 2004. p.159-163.

ALVAREZ, V.F.D.; MOLINA, R.L.; SAUCEDO, J.S Q. et al. Engorda postdestete en corral de borregos cruzados de Pelibuey en la época de otoño-invierno. In: REUNIÓN INTERNACIONAL SOBRE PRODUCCIÓN DE CARNE Y LECHE EN CLIMAS CÁlidos, 14., 2005, Mexicalí. Proceedings... Mexicalí: 2005. p. $136-140$.

BURKE, J.M.; APPLE, J.K. Growth performance and carcass traits of forage-fed hair sheep wethers. Small Ruminant Research, p.67, p.264-270, 2007.

BURKE, J.M.; APPLE, J.K.; ROBERTS, W.J. et al. Effect of breedtype on performance and carcass traits of intensively managed hair sheep. Meat Science, v.63, p.309-315, 2003.

CLARY, E.M.; BRANDT JR., R.T.,; HARMON D.L. et al. Supplemental fat and ionophores in finishing diets: Feedlot performance and ruminal digestion kinetics in steers. Journal of Animal Science, p.3115-3123, 1993 (Abstract). 
FLEET, M.R.; BENNIE, M.J.; DUNSFORD, G.N. et al. Lamb production from Merino ewes mated to Merino or Damara rams. Australian Journal of Experimental Agriculture, v.42, p.1027-1032, 2002.

GALYEAN, M.L.; HUBBERT, M.E. Rationale for use and delection of ionophores in ruminant production. In: SOUTHWEST NUTRITION AND MANAGEMENT CONFERENCE, 1989, Tucson. Proceedings... Tucson: University of Arizona, 1989. p.64-81.

INSTITUTO NACIONAL DE ESTADÍSTICA, GEOGRAFÍA E INFORMÁtICA - INEGI. Anuario Estadístico del Estado de Tamaulipas. Aguascalientes, México: 1995. 423p.

LANA, R.P.; FOX, D.G.; RUSSELL, J.B. et al. Influence of monensin on Holstein steers fed high-concentrate diets containing soybean meal or urea. Journal of Animal Science, v.75, p.2571-2579, 1997.

LEÓN, Á.E.; OLMOS, M.C.; CRUZ, E. et al. Accumulation of body fat in Cuban Pelibuey lambs according to age and feeding level. Archivos de Zootecnia, v.48, p.219-222, 1999.

MEDEIROS, C.M.; CARLOS, S.A.; DE BENI, A.M. et al. Effects of different levels of salinomycin on the performance and enzymatic functions in confined sheep. Ciência e Agrotecnologia, v.23, p.968-972, 1999.

NATIONAL RESEARCH COUNCIL - NRC. Nutrient requirements of small ruminants. Sheep, goats, cervids, and new world camelids. Washington, D.C.: The National Academy Press, 2007. 362p.

RANGEL, H.M.; NUÑEZ, O.M. Efecto de la aplicación de monensina sódica en la engorda de borregos de la raza Corriedale.
In: REUNIÓN NACIONAL DE INVESTIGACIÓN PECUARIA, 1992, Chihuahua. Memorias... Chihuahua, 1992. p.188.

RUSSELL, J.B.; STROBEL, H.J. Effect of ionophores on ruminal fermentation. Applied Enviroment Microbiology, v.55, p. 1-6, 1989.

SALINAS-CHAVIRA, J.; GARCIA-BARRERA, L.A.; CRUZBAUTISTA, H. et al. Effect of ionophore supplementation and trenbolone implant on growth and carcass characteristics of lambs. Journal Applied of Animal Research, v.28, p.49-52, 2005a.

SALINAS-CHAVIRA, J.; RAMIREZ, R.G.; LARA-PEDROZA. et al. Influence of monensin and salinomycin on growth and carcass characteristics in Pelibuey lambs. Journal Applied of Animal Research, v.28, p.93-96, 2005b.

SANTOS, A.J. Avaliação do ionóforo monensina sódica no consumo, digestibilidade, ganho de peso e $\mathrm{pH}$ ruminal em ovinos. 2005. 126f. Tese (Doutorado em Zootecnia) Universidade Federal de Lavras, Lavras.

SMITH, S.B.; CROUSE, J.D. Relative contributions of acetate, lactate and glucose to lipogenesis in bovine intramuscular and nutrition. Journal of Nutrition, v.3, p.792-800, 1984.

STEEL, R.G.D.; TORRIE, J.H. Principles and procedures of statistics. New York: McGraw-Hill Book, 1980. 622p.

TEDESCHI, L.O.; FOX, D.G.; TYLUTKI, T.P. Potential Environmental Benefits of Ionophores in Ruminant Diets. Journal Environment Quarterly, v.32, p.1591-1602, 2003.

WALLACE, R.J. Ruminal microbiology, biotechnology and ruminant nutrition: progress and problems. Journal of Animal Science, v.72, p.2992-3003, 1994. 